\title{
METODE LEARNING MANAGEMENT SYSTEM (LMS) IDU UNTUK MENDUKUNG KEGIATAN BELAJAR MENGAJAR MIT PADA PERGURUAN TINGGI RAHARJA
}

\author{
Untung Rahardja ${ }^{1}$ \\ Qurotul Aini ${ }^{2}$ \\ Siti Ria Zuliana ${ }^{3}$ \\ Jl. Jendral Sudirman No. 40, Modern Cikokol, Tangerang ${ }^{1,2,3}$ \\ Email: untung@raharja.info ${ }^{1)}$, aini@raharja.info ${ }^{2)}$, siti.ria@raharja.info ${ }^{3)}$
}

\begin{abstract}
ABSTRAK
Seluruh bidang telah ditunjang dengan teknologi, khususnya dunia pendidikan dalam proses belajar mengajar untuk menentukan mutu dari lulusan sebuah Perguruan Tinggi. Di dalam dunia pendidikan Perguruan Tinggi Raharja telah menerapkan metode pembelajaran iLearning untuk mencapai tujuan pembelajaran. Mahasiswa Pasca Sarjana diberikan pengalaman pembelajaran menggunakan metode iLearning yang proses pembelajaran nya menggunakan media Ten Pillar IT iLearning (TPi). Namun proses pembelajaran tersebut tidak berjalan semestinya dan masih bernuansa serba menggunakan kertas seperti metode pembelajaran pada umumnya, Maka dari itu saat ini untuk mencapai tujuan pembelajaran yang sangat efektif menerapkan Metode Learning Management System (LMS) menggunakan iDu dimana dapat diakses secara Online kapan saja dan dimana saja dengan Mudah. Tujuan penelitian ini untuk mengetahui mengukur keberhasilan proses pembelajaran pada kelas Mastering Information Technology (MIT) yang masih menggunakan sistem manual dalam proses pembelajarannya. Penelitian ini menggunakan pendekatan kuantitatif dengan metode survei deskriptif korelasional. Tehnik pengambilan sampel dalam penelitian ini didasari atas hasil survey dalam mahasiswa kelas MIT. Dengan Alat pengumpul data menggunakan kuesioner dan dokumentasi. Hasil dari penelitian menunjukkan bahwa semakin baik tingkat hasil proses pembelajaran menggunakan sistem iDu dimana mahasiswa bisa menyelesaikan pembelajaran dengan mudah dimana saja dan kapan saja. Dalam jurnal ini. diidentifikasikan ada 3 (tiga) permasalahan yang dihadapi dan solusi yang diberikan adalah dengan memanfaatkan campus Learning Management System (LSM) iDu. Dilakukan 8 (delapan) literature review sebagai bahan pembelajaran Pasca Sarjana. Dan tercatat ada 13 (tiga belas) kelebihan dan 1 (satu) kekurangan dari penelitian ini. Implementasi dilakukan pada matakuliah Mastering Information Technology (MIT). Dalam penelitian ini diharapkan dapat meningkatkan kualitas lulusan dari mahasiswa Pasca Sarjana di Perguruan Tinggi Raharja.
\end{abstract}

Kata Kunci : iDu, Pasca Sarjana, Pembelajaran

\begin{abstract}
Currently the entire field has been supported by technology, especially the world of education in the learning process to determine the quality of a college graduate. In the world of education Perguruan Tinggi Raharja has implemented iLearning learning methods to achieve the learning objectives. Graduate students are given learning experiences using methods iLearning the learning process using the media Ten Pillar IT iLearning (TPi). But the learning process is not running properly and still undeniably versatile use paper as a method of learning in general, Therefore at this time to achieve the learning objectives very effectively implement methods Learning Management System (LMS) iDu which can be accessed online anytime and anywhere easily. The purpose of this study to determine measure the success of the learning process at MIT class that still use manual systems in the learning process. This study uses a quantitative approach with descriptive correlational survey method . Sample collection techniques in this study was based on the results of the student survey MIT classes. Data collector by using questionnaires and documentation. Results from the study showed that the better level the results of the learning process to use iDu's system where students could complete the learning easily anywhere and anytime. In this journal Identified there are three (3) the problems
\end{abstract}


faced and the solutions given are by utilizing campus Learning Management System (LSM) iDu. Do 8 (eight) literature review as a post-graduate study materials. And there were 13 (thirteen) advantages and 1 (one) shortcomings of this study. The implementation is done in the course Mastering Information Technology (MIT). This study is expected to improve the quality of graduates from graduate students in Perguruan Tinggi Raharja.

Keyword: iDu, Postgraduate, Learning

\section{PENDAHULUAN}

Metode pembelajaran yang efektif adalah Metode yang digunakan dosen pengajar untuk mencapai tujuan pembelajaran yang diharapkan akan menghasilkan pembelajaran maksimal . Metode diskusi yaitu salah satu dari beberapa metode pembelajaran yang umum digunakan dalam dunia pendidikan karena disana antara mahasiswa saling berinteraksi lebih dekat, bekerja sama antar team belajar, dan saling mengutarakan pendapat yang sangat berguna serta dapat mewujudkan sesuatu hal yang baru jika disatukan dalam suatu sistem yang berguna bagi kelangsungan pembelajaran dalam perkuliahan. Dalam setiap metode pembelajaran yang diberikan pastinya akan memiliki kelebihan ataupun kekurangan, sehingga para dosen harus memahami berbagai metode pembelajaran dan menggunakan metode yang tepat sesuai dengan materi dan tujuan pembelajaran nya. Diharapkan mampu meningkatkan kemampuan peserta didik dalam proses berpikir dan mengungkapkan pendapat.

Perkembangan teknologi IT yang semakin berkembang, Perguruan Tinggi diharuskan melakukan inovasi dalam melaksanakan kegiatan akademik. Dalam hal ini sistem pembelajaran yang diimplementasikan perlu adanya sebuah inovasi baru, yakni diciptakannya pembelajaran yang tidak lagi menggunakan kertas sebagai medianya. Sehingga lebih praktis dan efisien. Sehingga kegiatan pembelajaran kurang menarik dan mahasiswa tidak dapat meng-eksplor kreativitasnya dalam belajar, karena sampai saat ini informasi tak lagi dapat diserap atau berwujud dengan mengandalkan perangkat-perangkat yang masih serba manual, oleh karena itu peran komputer yang diakses dengan mudah secara online sangatlah penting dalam memberikan suatu solusi dan merupakan alat bantu yang cukup baik dalam memperbaiki sistem yang belum optimal (manual). Selain itu, dengan adanya komputerisasi dapat mendukung dalam peningkatan mutu pelayanan suatu organisasi sehingga dapat meningkatkan perkembangan organisasi tersebut.

Dalam suatu sistem media informasi penyampaiannya masih menggunakan website, baik itu secara personal maupun teamwork. Namun mengingat semakin meningkatnya kebutuhan mahasiswa dan kualitas media informasi semakin baik, maka informasi yang dibutuhkan pun semakin meningkat khususnya mengenai media yang disampaikan dan media yang digunakan untuk penyampaian informasi, sehingga kualitas dan kuantitas sistem yang berjalan saat ini jauh lebih baik. Perguruan Tinggi Raharja dapat berfungsi melayani segenap lapisan masyarakat yang tersebar di seluruh Indonesia, dengan berbagai keragaman yang terdapat di dalamnya. Keragaman tersebut mencakup berbagai macam aspek, antara lain tingkat ekonomi, kesempatan belajar, ketersediaan sarana dan prasarana untuk belajar, cara belajar, kecepatan belajar serta motivasi belajar. Oleh karena itu, sebagai salah satu Perguruan Tinggi yang bergerak di bidang komputer harus selalu berinovasi untuk meningkatkan kualitas pembelajaran.

Metode Learning Management System (LSM) adalah Aplikasi perangkat lunak untuk kegiatan dalam jaringan, atau program pembelajaran elektronik dan secara Online (e-learning program), dan berisikan bahan pembelajaran serta pelatihan secara Online. Dengan memudahkan mahasiswa dalam proses pembelajaran secara Online dimana saja dan kapan 
saja dengan mudah. Perguruan Tinggi Raharja memiliki iDu sebagai media utamanya. iDu adalah media pembelajaran online menggunakan metode Campus Learning Management System (LSM) . Segala bentuk pembelajaran dapat dilakukan di iDu dengan mengkombinasikan tatap muka dan kegiatan belajar online melalui website idu.raharja.info bagi mahasiswa/i dan dosen. iDu dirancang dengan sangat fleksibel sehingga menghasilkan proses belajar yang berkualitas dengan bimbingan dosen berpengalaman yang telah lulus $i C P$ (iLearning Certified Professional) maupun iCM (iLearning Certified Master) dengan pembelajaran global. Melalui iDu mahasiswa/i dapat berinteraksi dengan dosen maupun sesama mahasiswa/i secara anytime dan anywhere. $\mathrm{iDu}$, gaya pembelajaran online masa kini terutama pada mahasiswa iLearning yang proses pembelajarannya menggunakan device yaitu iPad. Dengan forum Pribadi Raharja bisa saling bertukar pikiran dan saling berdiskusi, mudah dalam memahami bahan pelajaran, mudah dalam pengerjaan assignment dan ujian dari dosen.

\section{LANDASAN TEORI}

\section{Pengertian Learning Management System (LSM)}

Menurut Ryan K.Ellis dalam buku A Field Guide to Learning Management System (2009 :1) bahwa " Learning Managemet System, the basic description is a software application that automates the administration, tracking, and reporting of training events".

Ryan K.Ellis menjelaskan bahwa LMS adalah sebuah perangkat lunak atau software untuk keperluan administrasi, dokumentasi, pencarian materi, laporan sebuah kegiatan, pemberian materi-materi pelatihan kegiatan belajar mengajar secara online yang terhubung ke internet.

LMS digunakan untuk membuat materi pembelajaran online berbasiskan web dan mengelola kegiatan pembelajaran serta hasil-hasilnya. LMS ini sering disebut juga dengan platform e-learning atau learning content management system (LCMS). Intinya LMS adalah aplikasi yang mengotomasi dan memvirtualisasi proses belajar mengajar secara elektronik.

Menurut Barrit et al (2004, p233), Learning Management System merupakan alat yang digunakan untuk autentikasi, registrasi dan akses untuk pembelajaran.

Sedangkan menurut Shank et al (2004,p43), Learning Management System adalah aplikasi yang menangani tugas-tugas administratif seperti membuat katalog materi, mendaftarkan user, menelusuri user melalui materi dan menyediakan laporan mengenai user.

\section{Fitur - Fitur Learning Management System (LSM)}

Menurut Ryann K.Ellis, A Field Guide to LMS (2009:2) di dalam LMS juga terdapat fitur-fitur yang dapat memenuhi kebutuhan-kebutuhan dari pengguna dalam hal pembelajaran. Fitur-fitur yang terdapat dalam LMS pada umumnya antara lain :

1. Administrasi, yaitu informasi tentang unit-unit terkait dalam proses belajar mengajar. Fitur ini mengatur tentang kelengkapan belajar mengajar, antara lain : silabus, jadwal pelajaran, tugas, jadwal ujian, daftar referensi dan bahan bacaan. 
2. Penyampaian materi dan kemudahan akses ke sumber referensi, antara lain : bahan presentasi, contoh ujian yang lalu, situs-situs referensi, situs-situs bermanfaat, artikel dan jurnal online.

3. Penilaian, fitur yang menampilkan hasil-hasil kegiatan belajar mengajar yang telah berlangsung dan hasil evaluasi.

4. Ujian online

5. Komunikasi, fitur yang menyediakan sarana komunikasi bagi pengguna Learning Management System (LSM), antara lain : forum diskusi online, mailing list diskusi, chat.

\section{PERMASALAHAN}

Dalam pembelajaran Mastering Information Technology (MIT) Pasca Sarjana Di Perguruan Tinggi Raharja yang masih menggunakan sistem manual atau menggunakan kertas ini dapat menimbulkan beberapa masalah yaitu segi absen kehadiran mahasiswa, yaitu dimana saat mahasiswa yang absen mencantumkan tanda tangan mereka masing - masing. Dapat melakukan kecurangan saat dimana mereka tidak hadir di kelas dan hanya mencantumkan tanda tangan itu sudah melakukan kecurangan. Dan juga saat mahasiswa yang saat minggu lalu tidak hadir otomatis absensi mahasiswa tersebut kosong dan kemudian di minggu selanjutnya ia hadir dapat menambahkan tanda tangan saat minggu lalu ia tidak hadir. Dan dosen tidak akan mengetahui sebenarnya siapa mahasiswa yang benar - benar hadir di kelas atau hanya absensi. Itu dalam segi absensi kehadiran mahasiswa yang kurang efektif jika masih menggunakan sistem manual.

Pada sistem manual juga bahan pembelajaran yang dosen berikan pada mahasiswa akan manual yaitu berupa print out atau menggunakan papan tulis (white board), yang akan mengalami beberapa kendala yaitu tulisan dosen yang sulit untuk dipahami, print out pembelajaran yang dosen berikan akan hilang jadi saat akan digunakan untuk belajar akan mengalami kesulitan. Hal ini yang akan membuat keefektifan pembelajaran perkuliahan mahasiswa akan terganggu.

Dalam pembelajaran perkuliahan jika masih menggunakan sistem yang manual akan terjadi beberapa permasalahan yaitu dalam segi tugas yang diberikan dosen kepada mahasiswa. Dimana tugas yang masih menggunakan sistem manual akan berupa hardcover, maka akan mengalami beberapa kendala dalam pengumpulan tugas yaitu tugas dimana saat dosen meminta tugas tersebut dikumpulkan terkadang mahasiswa masih meminta untuk perpanjangan waktu,dimana tidak ada kedisiplinan dalam segi pengumpulan tugas. kemudian dalam segi tugas yang sudah diberikan selama perkuliahan tidak akan efektif (tidak tertata,tersimpan dengan baik) jika menggunakan sistem manual, dimana akan mengalami kehilangan tugas tugas yang sudah diberikan cukup lama, juga dimana tugas tugas yang tidak tersimpan dengan rapi, dan saat akan digunakan akan sulit untuk ditemukan karena sistem penyimpanan tidak efektif. serta terkadang jika ada tugas yang sudah diajukan ke dosen masih terjadi kesalahan maka mahasiswa harus merevisi tugas tersebut kembali dan akan memakan waktu serta biaya print out ulang yang cukup banyak. 


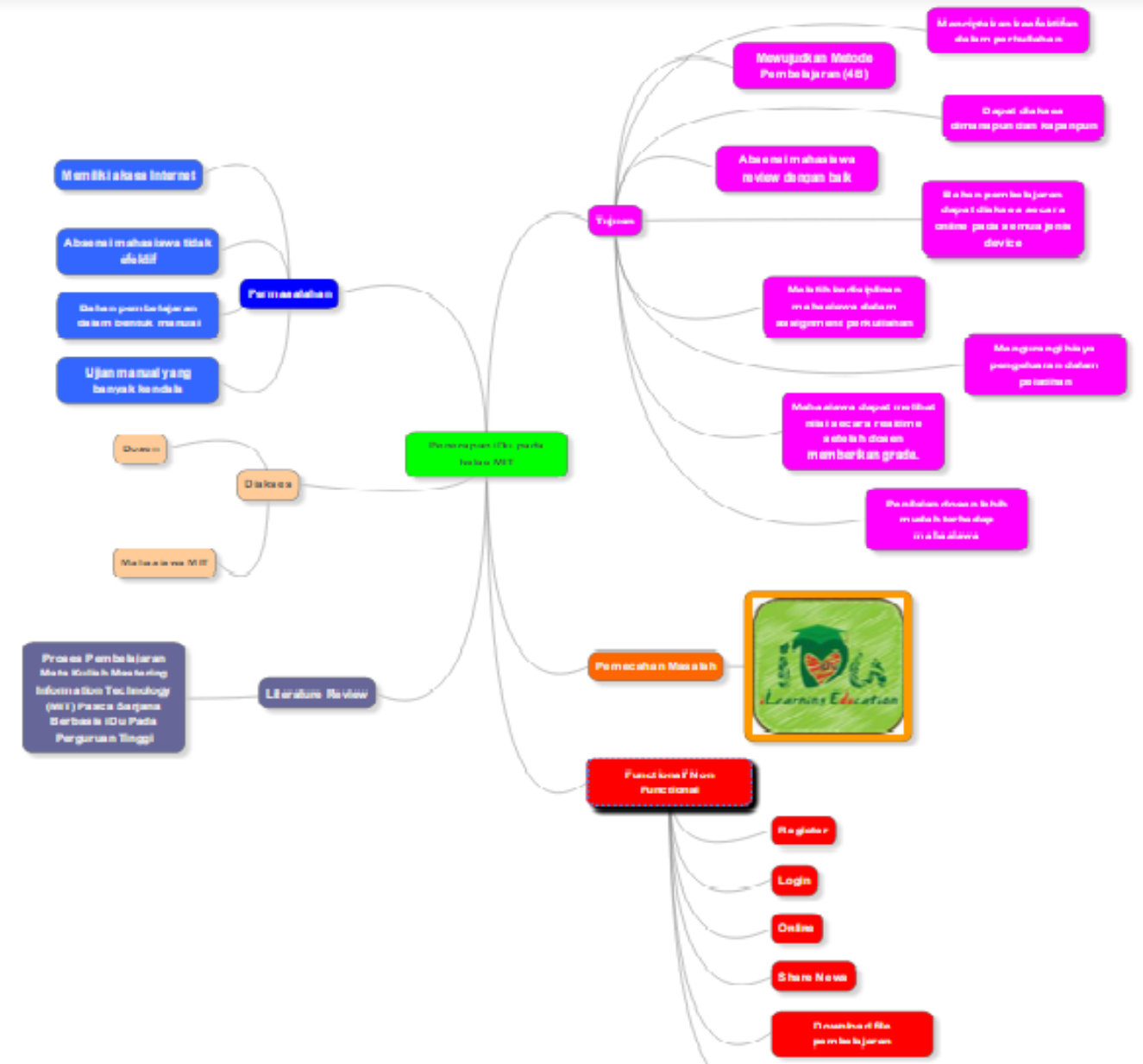

Gambar 1. Mind Mapping

Pada pembelajaran dalam perkuliahan yang masih manual, saat akan menghadapi ujian UTS atau UAS akan menggunakan kertas, dan akan terjadi beberapa kendala dalam ujian, hal tersebut akan membuat Ujian belum tercapai dengan sempurna, dimana masih terdapat banyak proses manual dan melibatkan banyak orang sehingga proses yang berjalan sangat panjang dan sulit. Jika ada satu orang yang menghambat maka seluruh proses menjadi terhambat sampai pada waktu pelaksanaan. Dosen harus meluangkan waktu banyak untuk membuat soal, setelah itu menemui Kajur (Kepala Jurusan) untuk menyerahkan soal tidak mencerminkan hal tersebut adalah proses yang mudah. Bagian terkait RPU juga harus teliti menyiapkan soal yang diserahkan oleh Kajur. Adapun banyak dosen yang kurang disiplin dengan menyerahkan soal tidak sesuai dengan format yang menyebabkan RPU harus meluangkan waktu melakukan edit soal. Pada proses ini RPU harus dipastikan bekerja dengan teliti dan cepat. Sehingga bagian RCC (Raharja Copy Centre) bisa langsung melakukan penggandaan soal. Proses penggandaan soal ini harus mengorbankan pemasukkan Perguruan Tinggi Raharja yang berkurang karena RCC akan tutup dalam waktu yang tidak dapat ditentukan untuk menyiapkan soal sehingga mahasiswa tidak dapat memanfaatkan fasilitas yang ada. Dan penggandaan soal membutuhkan kertas yang sangat banyak, Proses penggandaan pun akan terjadi kesalahan. Bahkan tinta dan mesin fotocopy harus dipastikan dalam kondisi baik, jika kehabisan tinta atau mesin tersebut sedang mengalami kerusakan maka proses persiapan soal akan terhambat. Kendala tidak berhenti pada bagian ini, selesai proses penggandaan soal kesiapan dan tanggung jawab panitia packing soal diuji karena sering terjadi rasa malas untuk mengerjakan hal ini. Panitia yang mengerjakan packing soal harus sejenak meninggalkan rutinitas harian mereka, sehingga pekerjaan rutin menjadi terhambat. Dalam proses ini panitia harus sangat teliti agar tidak terjadi kesalahan dalam 
packing. Panitia juga harus menyiapkan 1 (satu) ruang untuk meletakkan soal yang telah selesai di packing. Pada sistem ujian yang masih manual Pengawas akan ditugaskan untuk membagikan soal-soal kepada mahasiswa dengan cara berkeliling sesuai dengan kode kelas, pada hal ini terkadang terjadi soal yang tidak sesuai yang menyebabkan kerugian pada pihak mahasiswa. Soal yang telah dipisahkan dengan lembar jawaban akan diserahkan secara langsung oleh Pengawas kepada dosen yang bersangkutan, dalam proses mengoreksi lembar jawaban dengan jumlah yang sangat banyak. Dengan proses yang begitu panjang beberapa waktu untuk kemudian mahasiswa baru bisa melihat hasil dari ujian di Perguruan Tinggi Raharja.

Dalam penilaian sistem manual kemungkinan nilai hasil tugas-tugas mereka akan tercecer atau akan hilang jadi saat mereka ingin mereview nilai-nilai pada semester tersebut akan terjadi kesulitan karena nilai-nilai nya tidak terdaftar dengan baik pada suatu sistem.

Sistem perkuliahan yang masih manual akan terjadi kesulitan untuk dosen mengetahui presentase nilai mahasiswa yang mendapatkan nilai $\mathrm{A}+, \mathrm{A}, \mathrm{A}-, \mathrm{B}+$ dan seterusnya. Karena jika manual dicatat saja sulit untuk melakukan perkiraan presentase yang diperoleh, belum lagi jika catatan tersebut dosen mengalami kehilangan catatan tersebut. Cukup mengalami kesulitan bagi dosen untuk mengetahui mahasiswa yang nilainya cukup besar dan sebaliknya jika tidak dilihat dalam suatu diagram presentase.

Email Raharja info (Rinfo) adalah layanan komunikasi email yang disediakan oleh Perguruan Tinggi Raharja untuk semua Pribadi Raharja, alat komunikasi utama dan paling vital untuk para Pribadi Raharja[1]

\section{LITERATURE REVIEW}

Kumpulan penelitian yang sebelumnya dilakukan berkenaan dengan Literature Review mengenai konsep antara diskusi dengan teknologi. Dalam upaya mengembangkan iDu pada program Pasca Sarjana ini perlu dilakukan studi pustaka sebagai salah satu dari penerapan metode penelitian yang akan dilakukan. Diantaranya adalah mengidentifikasikan kesenjangan dan mengidentifikasikan metode yang pernah di lakukan, meneruskan penelitian sebelumnya, serta untuk mengetahui orang lain yang spesialisasi dan area penelitiannya sama di bidang ini. Beberapa Literature Review tersebut adalah sebagai berikut :

1. Penelitian yang dilakukan oleh Maimunah, Kristiana dan Hendra dari Perguruan Tinggi Raharja tahun 2010 yang berjudul "Perancangan Aplikasi Forum Diskusi Pada Media E-Learning Berbasis Web". Penelitian tersebut menjelaskan bahwa pentingnya forum diskusi dalam proses belajar-mengajar. Oleh, karena itu dibuatlah aplikasi forum diskusi untuk pembelajaran "e-learning" yang dapat mengkomunikasikan peserta didik dengan pengajar dimana aplikasi ini dapat menghemat waktu belajarmengajar, mengurangi biaya perjalanan, menghemat biaya pendidikan, dan mampu menjangkau wilayah geografis yang lebih luas serta melatih pelajar agar lebih mandiri dalam mendapatkan ilmu pengetahuan.[2]

2. Penelitian yang dilakukan oleh Matthew Young Kim di Kennesaw State University Kennesaw, GA, USA. Pada tahun 2011 dengan judul "Simulation Study of eLearning Classroom using iPads Based on Wireless LAN with IEEE 802.11b" menyajikan studi simulasi kelas e-Learning menggunakan iPad sebagai perangkat mobile berbasis pada LAN nirkabel dengan protokol IEEE 802.11b. Selain itu, makalah ini menyajikan sebuah studi simulasi apakah IEEE 802.11b dapat mendukung hingga 25 iPads dari 
kelas e-Learning tanpa masalah keadilan pada Wireless LAN bersama. Simulasi dilakukan dengan OPNET IT Guru Academic Edition 9.1.[3]

3. Penelitian ini dilakukan oleh Atmoko Nugroho dari Universitas Semarang pada tahun 2012 yang telah terbit di Jurnal Transformatika, Volume 9 No 2, Januari 2012 : 72 78. Dengan judul "Pengembangan Model Pembelajaran Jarak Jauh Berbasis Web (Model Development of Web-Based Distance Learning)". Yang dibahas dalam penelitian ini yaitu proses pembelajaran yang dilakukan dengan jarak jauh namun tetap memiliki kualitas yang baik dengan adanya sistem acak untuk materi dan soal. Dan proses pembelajaran tidak lagi terkendala waktu dan lokasi.[4]

4. Penelitian ini dilakukan oleh Untung Rahardja, Muhamad Yusup dan Eva Rosyifa dari Perguruan Tinggi Raharja tahun 2012 yang berjudul "Perancangan Aplikasi iLearning Majalah Online Dengan Menggunakan iOS Programming Pada Perguruan Tinggi”. Penelitian ini membahas sifat publikasi penyampaian informasi bersifat penting karena dapat membantu dan melakukan pencarian akan informasi yang sebelumnya tidak diketahui. Serta media publikasi masih berkaitan satu sama lain sehingga kebutuhan akan informasi sifatnya masih sangat tinggi dan dari sebagian tempat sifatnya masih sangat rendah dan proses update akan informasi masih bersifat minim. Sehingga diharuskan melakukan perancangan aplikasi iLearning majalah online dengan menggunakan iOS Programming, yang diharapkan bisa di akses melalui iPhone dan iPad yang bisa di download melalui iTunes demi meningkatkan peran media dalam perguruan tinggi supaya jauh lebih baik dan tentunya bermanfaat.[5]

5. Penelitian yang dilakukan oleh Henderi, Muhamad Yusup dan Yulika Ayu Rantama pada tahun 2012 dengan judul "Penggunaan Metode iLearning Untuk Meningkatkan Kualitas Pembelajaran Di Perguruan Tinggi". Penelitian membahas bagaimana caranya untuk bisa menerapkan suatu sistem baru dalam hal ini ialah iLearning. Segala sesuatu banyak dipersiapkan untuk bisa menerapkan iLearning, pertama yang dilakukan yaitu Training RiJP (Raharja iLearning Junior Professional), Training iCP dan Sandbox Meeting.[6]

6. Penelitian ini dilakukan oleh Dewi Immaniar Desrianti, Untung Rahardja dan Rahma Rinie pada tahun 2013 dengan judul "iLearning Metode Belajar Efektif Untuk Sekolah Tinggi". Dalam penelitian ini dibahas sebuah metode pembelajaran yang memiliki fasilitas memadai kebutuhan dalam pembelajaran yaitu sebuah metode pembelajaran baru yang bernama iLearning. Dengan menggunakan metode pembelajaran iLearning ini dapat menunjang dalam proses belajar mengajar. Salah satu media yang menyediakan berbagai aplikasi untuk pembelajaran iLearning yaitu iPad. Karena iPad memiliki aplikasi atau fitur-fitur yang cukup lengkap untuk metode iLearning.[7]

7. Penelitian ini dilakukan oleh Untung Rahardja, Muhamad Yusup dan Qurotul Aini dari Perguruan Tinggi Raharja pada tahun 2014 yang berjudul "Aplikasi Campus Learning System iOU (integrated Online Ujian) Dalam Mendukung Kegiatan iLearning Education (iDu) Pada Perguruan Tinggi". Penelitian ini membahas mengenai alternatif pemecahan masalah ujian yang masih menggunakan paper based dengan menerapkan Campus Learning System iOU (integrated Online Ujian) berbasis computer based pada Perguruan Tinggi Raharja. Dengan iOU yang berbasis computer based mahasiswa dapat mengerjakan soal- soal ujian pada komputer yang merandom soal-soal tersebut, yang juga menjadikan mahasiswa dapat mengerjakan soal dalam waktu yang bersamaan tetapi masing-masing mengerjakan soal berbeda. 
Dalam pengerjaan soal $i O U$ juga terdapat batas waktu memulai dan mengakhiri soalsoal tersebut. Dan mahasiswa beserta dosen dapat langsung mengetahui nilai akhir dari pengerjaan soal-soal ujian tersebut.[8]

8. Penelitian ini dilakukan oleh Meta Amalya Dewi, Dede Cahyadi, Yunita Wulansari dari Perguruan Tinggi Raharja pada tahun 2014 yang berjudul "Sistem Ujian Online Calon Mahasiswa Baru Berbasis iLearning Education Marketing Pada Perguruan Tinggi Raharja”. Penelitian ini membahas mengenai sistem pelayanan Ujian Seleksi Masuk (USM) untuk Calon Mahasiswa Baru (CMB) yang dilakukan secara online.[9]

Dari 8 (delapan) literature review yang ada, telah banyak penelitian mengenai metode pembelajaran menggunakan media iDu, Itulah alasan mengapa penulisan ini membahas hal tersebut. Agar nanti bisa dijadikan acuan sebagai referensi oleh dosen maupun mahasiswa. Dalam hal ini forum diskusi sangat berguna saat belajar-mengajar berlangsung. Maka terciptalah "e-learning" disanalah wadah mahasiswa berinteraksi serta menghemat waktu , biaya serta melatih mandiri dalam mendapatkan ilmu pengetahuan. Dengan mandiri berusaha melakukan pembelajaran sendiri dengan jarak jauh tetap berkualitas baik tidak mendapatkan kendala. Mempublikasikan penyampaian informasi bersifat penting Serta media publikasi masih berkaitan satu sama lain sehingga kebutuhan akan informasi sifatnya masih sangat tinggi. Sehingga diharuskan menciptakan aplikasi iLearning majalah online dengan menggunakan iOS Programming, yang diharapkan bisa di akses melalui iPhone dan iPad yang bisa di download melalui iTunes demi meningkatkan peran media dalam perguruan tinggi supaya jauh lebih baik dan tentunya bermanfaat dan terciptalah Sistem iLearning metode pembelajaran yang memiliki fasilitas memadai kebutuhan dalam pembelajaran yaitu sebuah metode pembelajaran baru yang bernama iLearning. Dengan menggunakan metode pembelajaran iLearning ini dapat menunjang dalam proses belajar mengajar.serta dapat diterapkan dalam sistem pelayanan Ujian Seleksi Masuk (USM) untuk Calon Mahasiswa Baru (CMB) yang dilakukan secara online bagi mahasiswa bagi yang akan bergabung pada Perguruan Tinggi Raharja.

\section{PEMECAHAN MASALAH}

Untuk mengatasi masalah yang timbul pada sistem yang masih manual penerapan sistem informasi yang akurat. Kecanggihan iPad yang dimanfaatkan sebagai media penunjang berjalannya iLearning di Perguruan Tinggi Raharja. Kini belajar bukan hanya didalam kelas, bukan hanya di atas kertas, namun dengan iLearning kita menunjukan bahwa bisa belajar dimanapun dan kapanpun dapat dilakukan. Aktifitas apapun adalah belajar. Saat bermain dengan jari dan $\mathrm{iPad}$, saat itulah sedang belajar. Menjelajahi dunia maya dengan mencari informasi yang sangat kaya dan berkualitas tentunya itulah belajar yang sesungguhnya. Bila mendefinisikan belajar adalah membaca, menulis, tentunya itulah metode pembelajaran yang kuno. Kita butuh perubahan karena kini dunia sudah begitu maju dan akan selalu membutuhkan perkembangan dari berbagai sisi.

Segi absen kehadiran mahasiswa memerlukan absen online dengan menggunakan perangkat komputer yang berakses internet. Dimana jika absen kehadiran mahasiswa diberlakukan online maka tidak akan ada mahasiswa yang melakukan titip absen kepada teman ataupun hanya hadir di absen namun di kelas tidak hadir karena saat melakukan absen tersebut dosen langsung bertatap muka pada mahasiswa . semua hal tersebut tidak akan terjadi dan dosen pun mengetahui atau dapat memantau mahasiswa yang masuk dan tidak masuk di dalam kelas. 

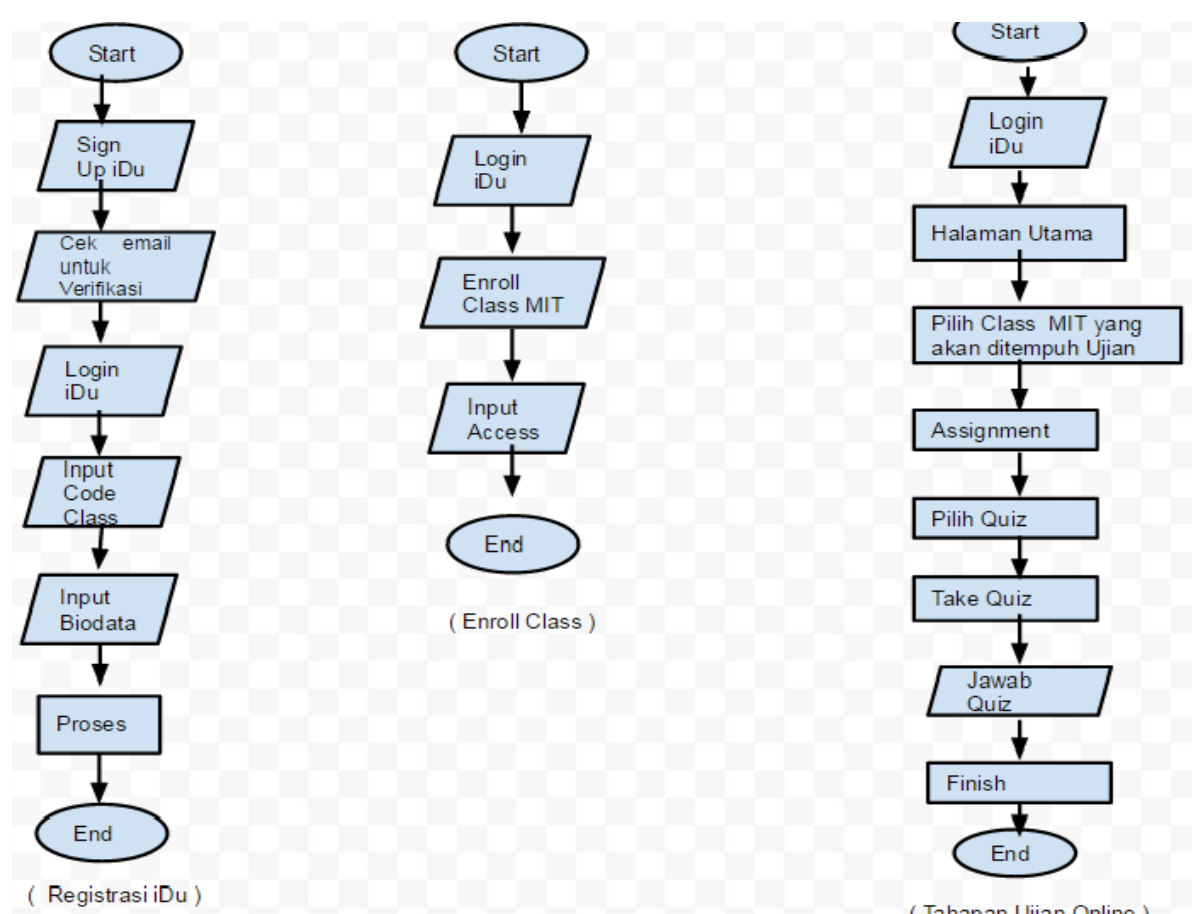

Gambar 2. Flowchart Alur sistem yang berjalan

Bahan pembelajaran yang tidak efektif akan menjadi efektif dan lancar serta tidak menghambat mahasiswa dalam perkuliahan dengan diciptakannya suatu sistem untuk mendukung sistem pembelajaran iLearning. Sistem tersebut adalah iDu (iLearning Education) merupakan media pembelajaran online menggunakan metode Campus Learning Management System (LSM) iDu. Segala bentuk pembelajaran dapat dilakukan di iDu dengan mengkombinasikan tatap muka dan kegiatan belajar online melalui website iDu bagi mahasiswa/i dan dosen. $i D u$ dirancang fleksibel sehingga menghasilkan proses belajar yang berkualitas dengan bimbingan dosen berpengalaman yang telah lulus iCP (iLearning Certified Professional) maupun iCM (iLearning Certified Master) dengan pembelajaran global. Melalui $i D u$ mahasiswa dapat berinteraksi dengan dosen maupun sesama mahasiswa/i secara anytime dan anywhere. iDu, gaya pembelajaran online masa kini. Dimana dosen dapat menyimpan bahan perkuliahan pada sistem $i D u$ ini dengan bentuk docs ataupun keynote yang dapat kita unduh dan disimpan pada laptop ataupun ipad untuk pembelajaran dirumah jika tidak memiliki akses internet.

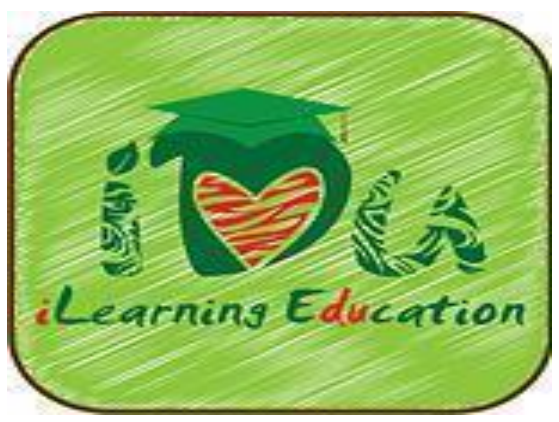

Gambar 3. Logo iDu

Pada sistem ini juga assignment (tugas) yang dosen berikan akan lebih mudah dikerjakan dan juga dapat membuat mahasiswa lebih disiplin dalam pengumpulan tugas. Dimana tugas yang diberikan dalam sistem ini akan mempermudah mahasiswa dikelas tidak menggunakan manual (kertas) soal yang diberikan pada sistem ini akan jelas karena dosen langsung yang membuatnya, serta melatih mahasiswa yang malas untuk rajin dalam 
mengerjakan tugas karena dalam sistem ini dosen dapat memberikan beberapa waktu dalam pengerjaan tugas tersebut. Saat mahasiswa tidak mengerjakan diwaktu yang sudah dosen berikan (keterlambatan) waktu maka mahasiswa tersebut sudah tidak bisa mengerjakan soal tersebut. Dan harus menghubungi dosen yang bersangkutan untuk meminta perpanjangan waktu. Dari sana lah dosen paham dan mengetahui siapa saja yang suka melakukan keterlambatan dalam mengerjakan tugas yang sudah diberikan. Namun nilai yang diberikan akan sesuai waktu mahasiswa saat mensubmit tugas tersebut.

Kelebihan lain pada sistem ini adalah Dengan pelaksanaan Ujian Online ini, maka peserta ujian atau Mahasiswa diwajibkan untuk mempersiapkan diri dengan membawa iPadnya masing-masing dan terhubung dengan sambungan internet/Wifi pada jadwal yang telah ditentukan. Adapun jadwal ujian dapat dilihat melalui KPU (Kartu Peserta Ujian) masingmasing. iOU (integrated Online Ujian) pada kampus Perguruan Tinggi Raharja saat ini belum diperuntukkan untuk semua mata kuliah. Saat ini masih diperuntukkan untuk konsentrasi iLearning yang diselenggarakan ujian secara online, karena kelas iLearning adalah kelas yang menggunakan pembelajaran menggunakan media iPad. Setelah itu mahasiswa akan mendapatkan nilai setelah mahasiswa mensubmit atau melakukan finishing dalam pengerjaan tugas. Jadi tidak perlu menunggu waktu lama untuk mengetahui hasil tugas dan Ujian Online. Dan dengan sistem ini lah yang sangat mendukung pembelajaran mahasiswa dari semua segi bahan pembelajaran, tugas yang diberikan dosen, Ujian Online, Nilai - nilai hasil pembelajaran tiap harinya akan tertata rapi tanpa takut kehilangan data tersebut.

Kelebihan dari penerapan sistem berbasis iLearning Education (iDu) ini pada mata kuliah Mastering Information Technology (MIT) sangat berbeda dengan sistem yang lain. Karena sistem ini mempunyai beberapa ciri khas yang menjadi unggulan untuk meningkatkan proses pelatihan agar lebih fun dan memudahkan kedua belah pihak. Dirangkum menjadi 12 kelebihan yang terdapat dalam sistem ini dalam proses pembelajaran:

1. Single Sign On (SSO) with Raharja Info (RInfo).

2. Simple, powerful and easy tu used.

3. Dapat diakses disegala macam device.

4. Memiliki perpustakaan soal.

5. Terdapat 9 (sembilan) macam jenis soal seperti quizzes, freeform, offline, survey, debate, dropbox, team, discussion and SCORM.

6. Terkolaborasi dengan tools seperti skype, forum dan group.

7. Menjadikan proses pembelajaran yang berkualitas.

8. Memudahkan dosen dalam penilaian.

9. Mahasiswa dapat melihat nilai secara realtime setelah dosen memberikan grade.

10. Memudahkan mahasiswa dalam mengerjakan assignments.

11. Menjadikan mahasiswa lebih aktif dengan praktikum yang ada.

12. Mengurangi biaya dalam proses pelatihan.

13. Dapat diakses dimana saja dan kapan saja.

Sistem berbasis iLearning Education (iDu) juga masih mempunyai kekurangan diataranya:

1. Hanya dapat diakses secara online.

\section{IMPLEMENTASI}

Tampilan website iDu yang memiliki berbagai macam fitur yang dapat digunakan oleh mahasiswa maupun dosen dalam proses pembelajaran berkualitas yang terdiri dari: 
a. Halaman Utama

$i D u$ dapat diakses dimana saja dan kapan saja oleh dosen maupun mahasiswa dengan menuju alamat http://idu.raharja.info

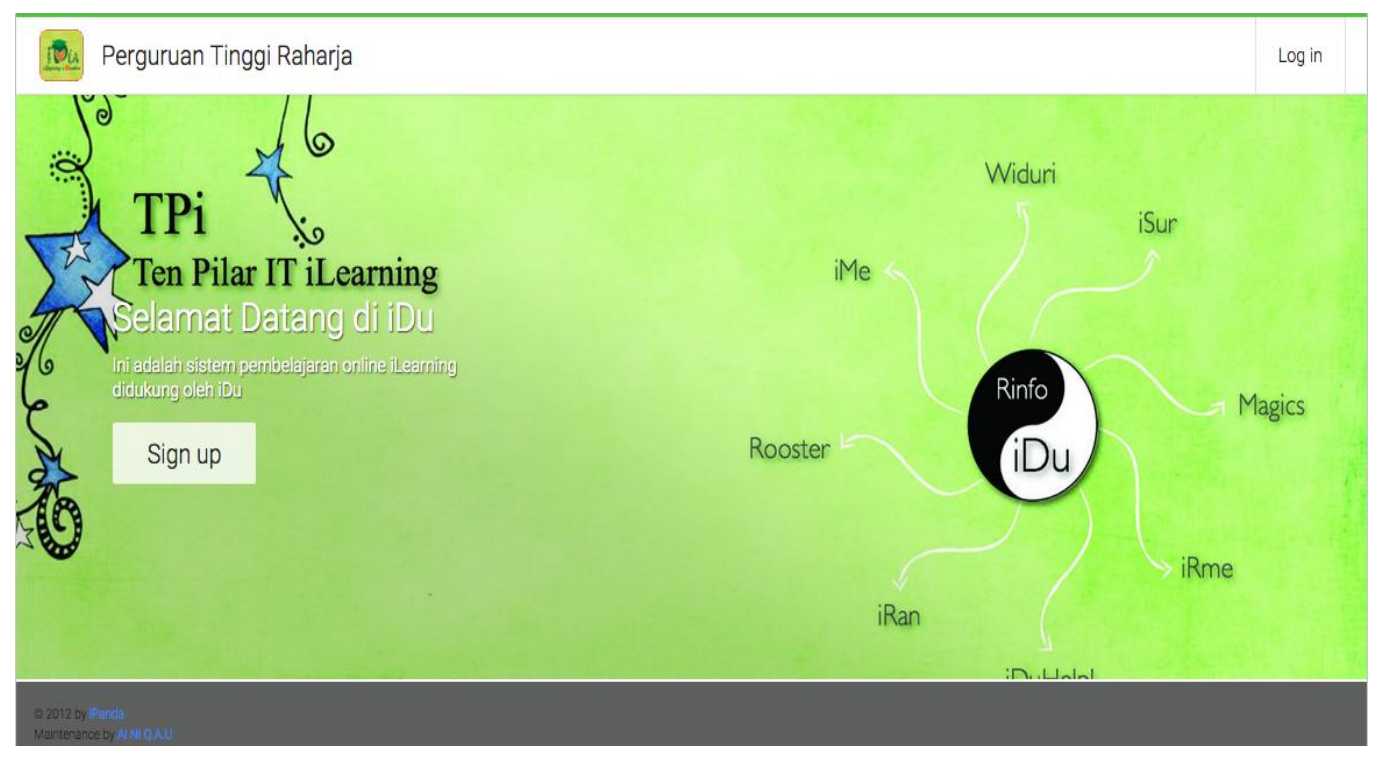

b. Tampilan News pada $i D u$

Setelah user yaitu dosen melakukan log in maka akan mengarah ke News. Dan tampilan News ini akan berisi seputas informasi kampus, dimana seluruh user iDu dapat melakukan comment pada News yang ada.

\begin{tabular}{|c|c|c|c|}
\hline Classes & + Post Announcement & 0 & To-do \\
\hline \$ Groups & iLearning eDucation & & F. Upload logo \\
\hline Q Dastboard & $\begin{array}{l}\text { Hiipribadi Rahaja, } \\
\text { Selamat menempun semester genaa TA. 2014/2015 }\end{array}$ & & Notifications \\
\hline News & Semoga semua bejalan lancar dan dapat mengikut perkuliahan dengan baik. & & : 10 friend requests \\
\hline \& Users & $\begin{array}{l}\text { Dan mendapatkan hasil yang tertaik. } \\
\text { Contribute more! }\end{array}$ & & 24 user reports \\
\hline$\cong$ Reports & Warm regards' & & Announcements \\
\hline Admin & iDuTeam^^. & & A Hi Pribadi Rahara, Sela.. \\
\hline Myclasses & 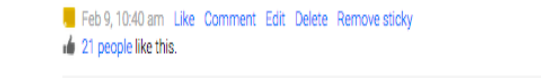 & & 19. Hi everyone, we just upd... \\
\hline Wd Phototography & Rat Munammad Nur Rifai & & Whi everyone, as part of ou. \\
\hline latal Fantassy & Feb 24, 1129 an Like Comment: Edit Delete & & $\begin{array}{l}\text { Whi lieveryone, we just adde... } \\
\text { Gonive integation in the HT... }\end{array}$ \\
\hline$\underline{\theta}$ iou & Fid Rinaldi A amin & & $\begin{array}{l}\text { Hi everyone, By popular d... } \\
\text { Coming soon. free archiving... }\end{array}$ \\
\hline 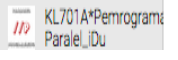 & Mar 1,253 am Like Edit Delete & & $v$ \\
\hline
\end{tabular}

c. Tampilan Assignment pada iDu

Dalam assignments ini berisikan tugas - tugas yang diberikan oleh dosen pengajar. Tampilan assignments ini dapat dilihat secara detail mulai dari start and due dari assignments, score yang diberikan dan ada berapa jumlah mahasiswa yang submit ditiap assignment yang diberikan. 


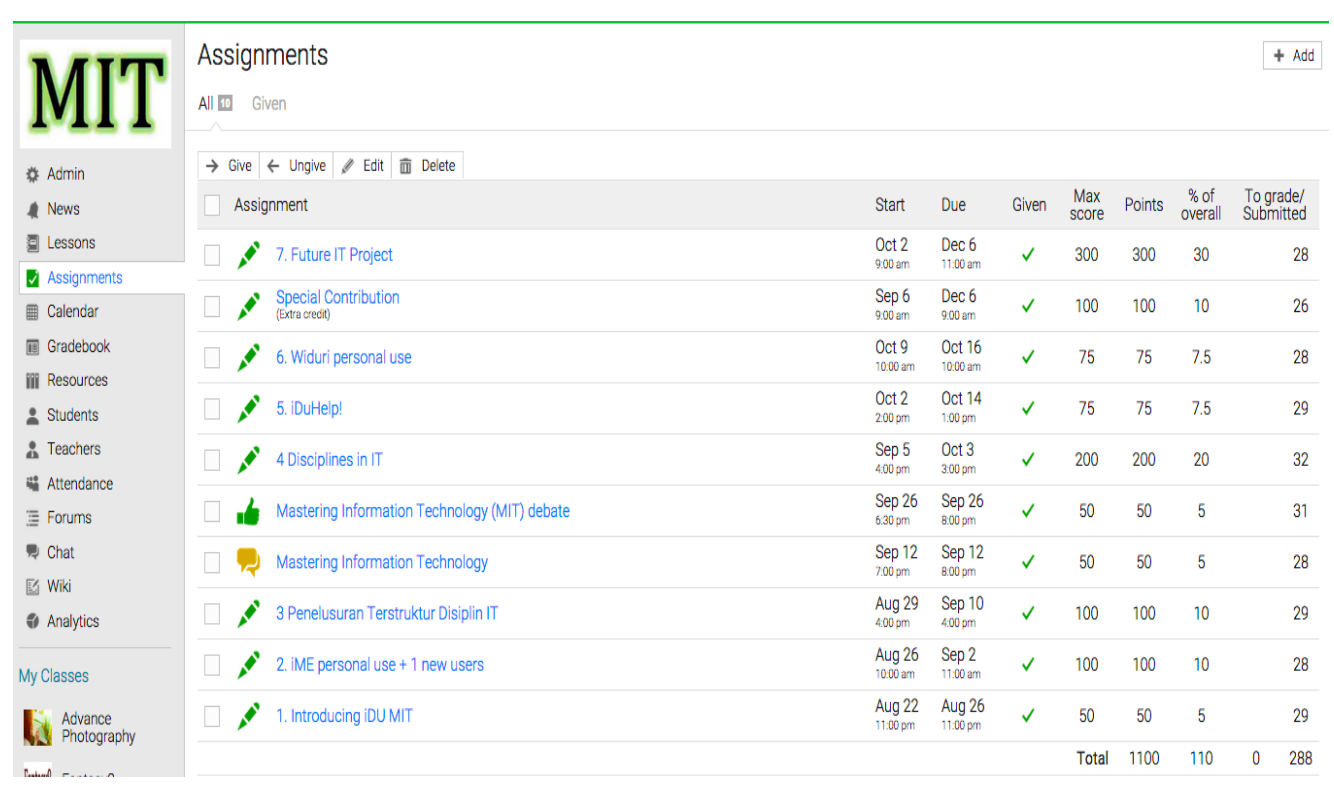

d. Tampilan

Gradebook

pada

$i D u$

Pada tampilan gradebook ini adalah hasil dari seluruh mahasiswa atas assignments yang sudah di give oleh dosen mata kuliah Mastering Information Technology (MIT). Dan gradebook ini dapat di export dengan hasil CSV untuk memudahkan pihak RPU dan REC dalam menginput hasil ke dalam daftar nilai mahasiswa.

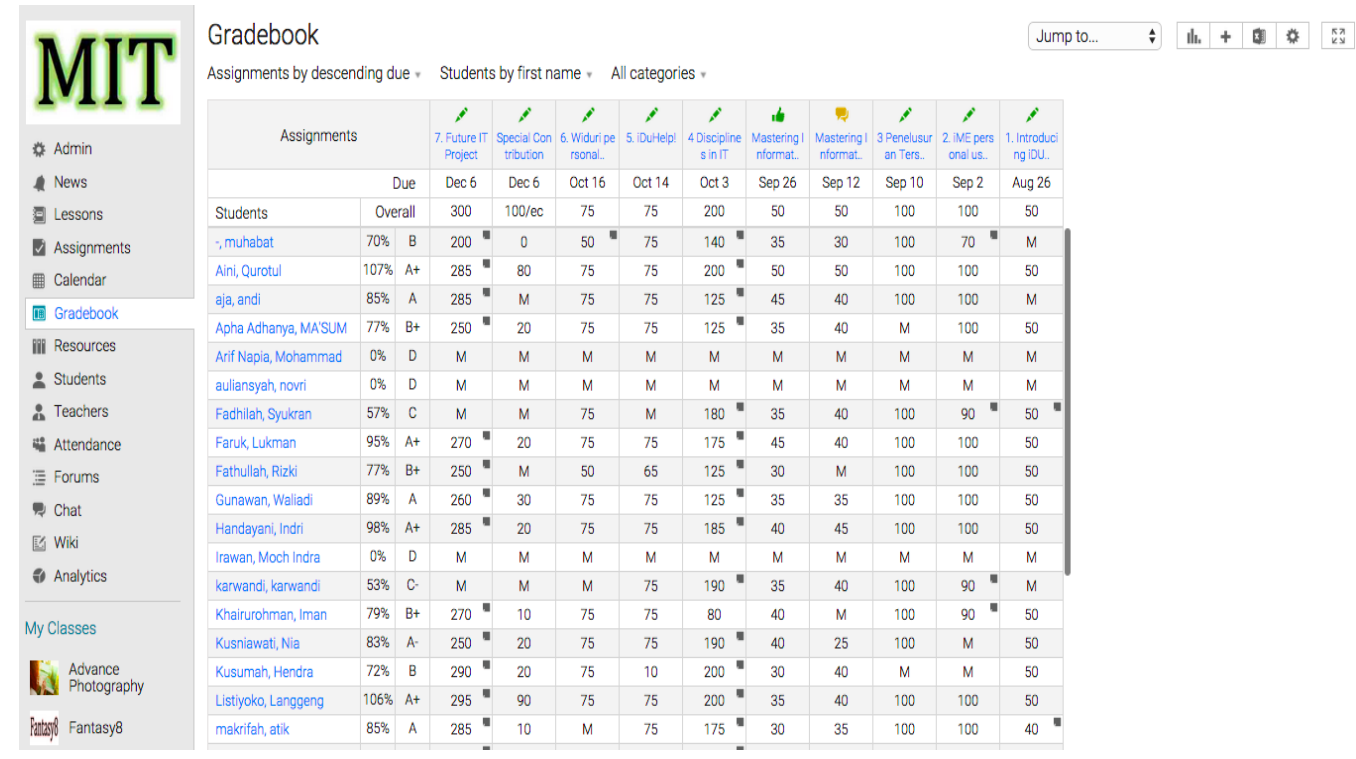

e. Tampilan Student pada $i D u$

Di dalam $i D u$ ini dosen dapat melihat seluruh keaktifan mahasiswa secara keseluruhan dan simpel. Dimana secara singkat dapat dilihat progress dari keaktifan mahasiswa dan juga dapat dilihat secara detail melalui pilihan More. Dimana pada tampilan More ini dosen dapat melihat secara satu persatu dari mahasiswa mulai dari grade keseluruhan, assignment apa saja yang sudah di submit, awards. Dan juga tampilan tersebut dapat dilihat dalam versi PDF untuk bisa di save kemudian di print. 
ISSN : 2356 -5209

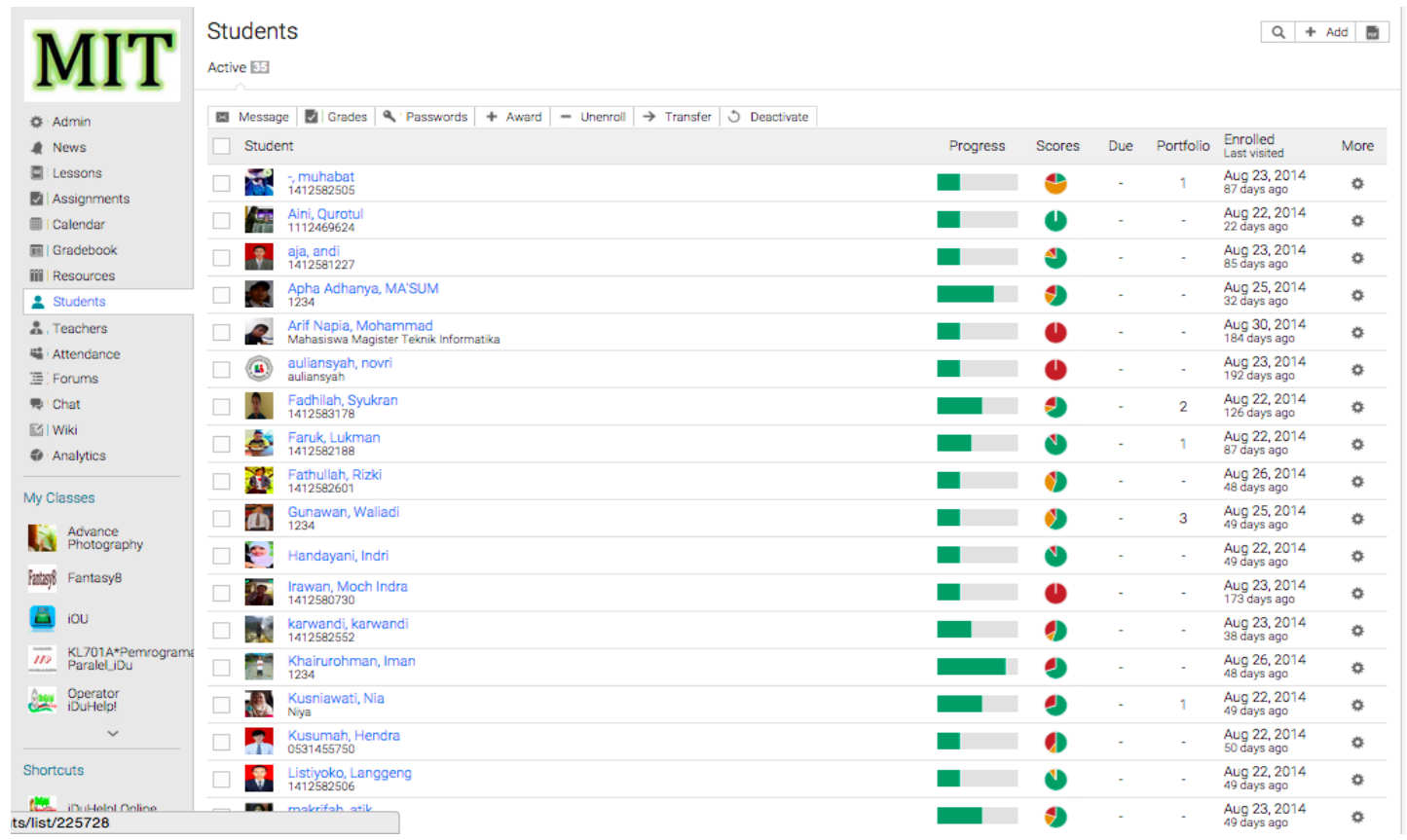

f. Tampilan Teachers pada $i D u$

Disini dapat dilihat siapa dosen pengajar mata kuliah ini, yaitu Untung Rahardja. Jika dosen pengajar memiliki asisten dosen maka dapat dilakukan dengan menggunakan click Add

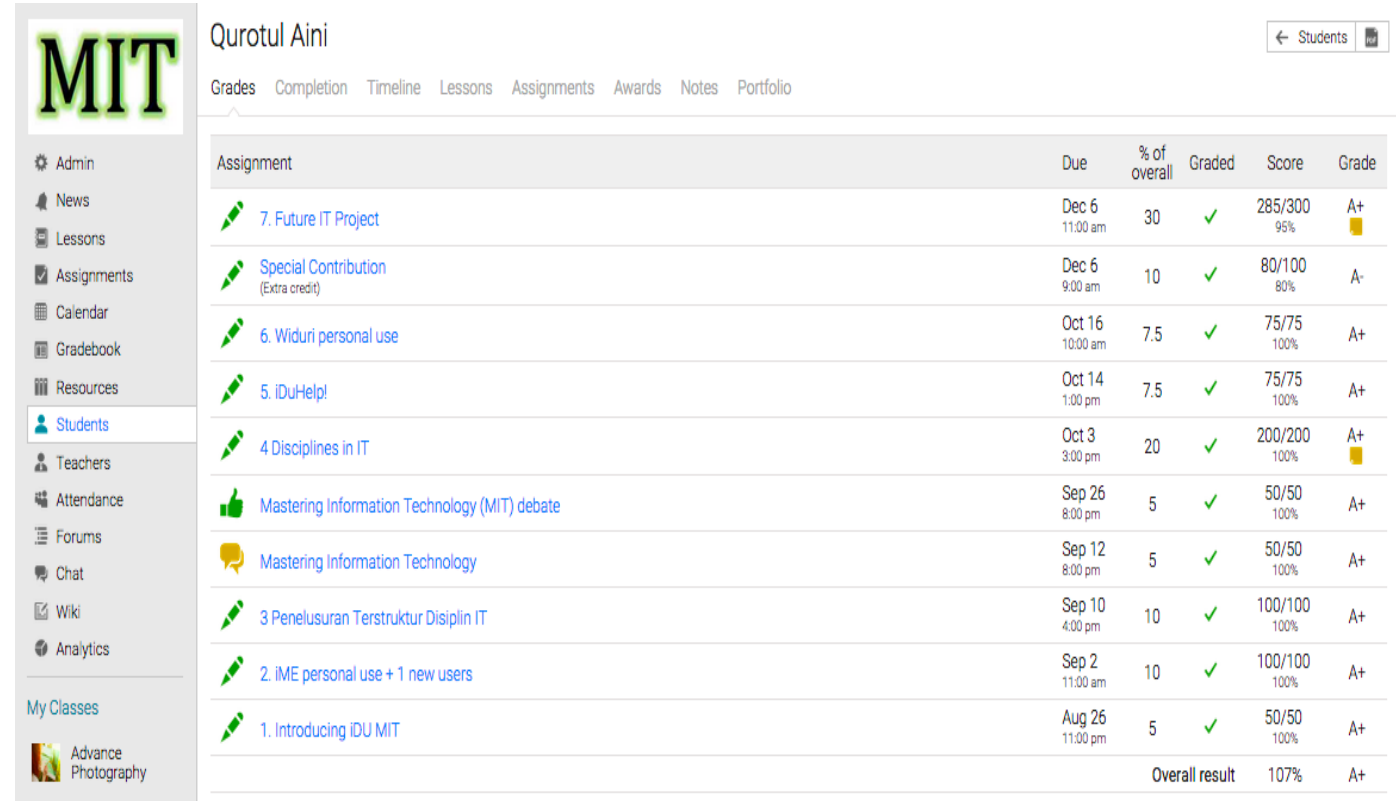


ISSN : $2356-5209$

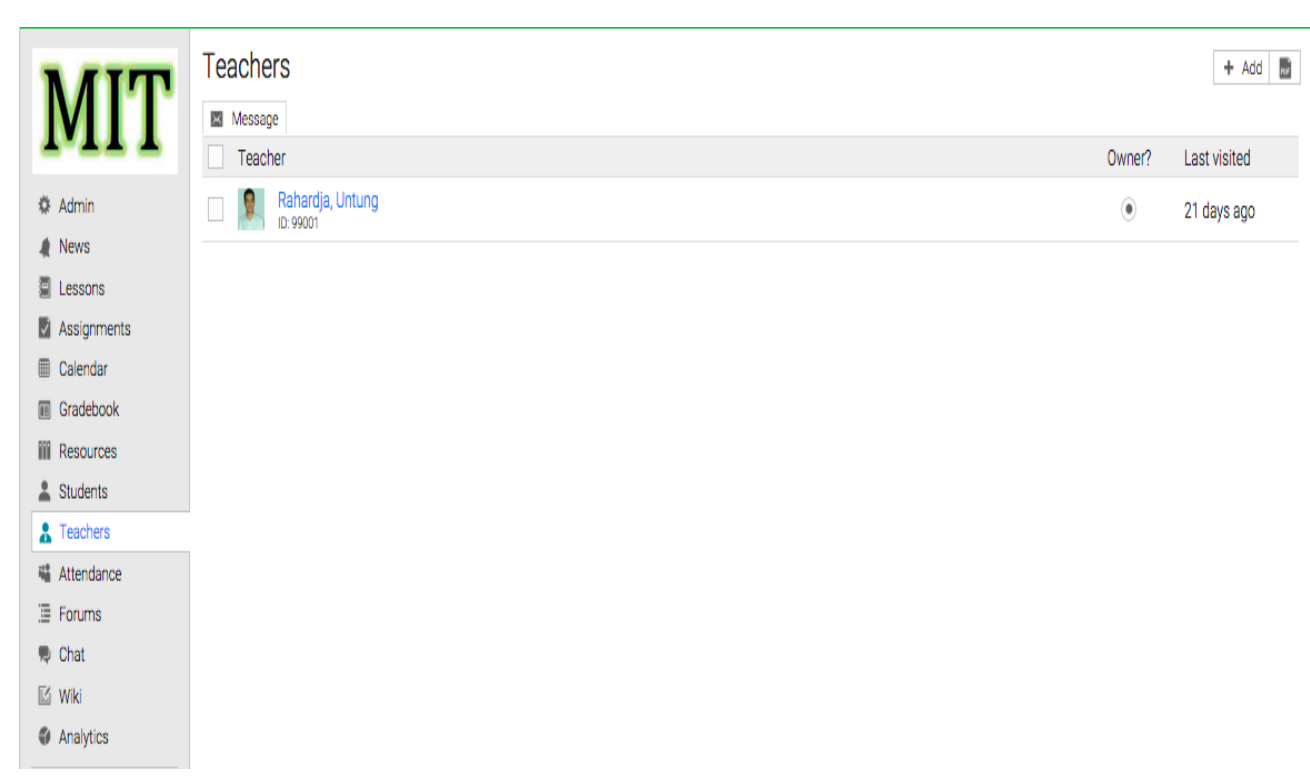

g. Tampilan Attendance pada $i D u$

Dalam tampilan ini berisikan absen mahasiswa selama mengikuti perkuliahan.

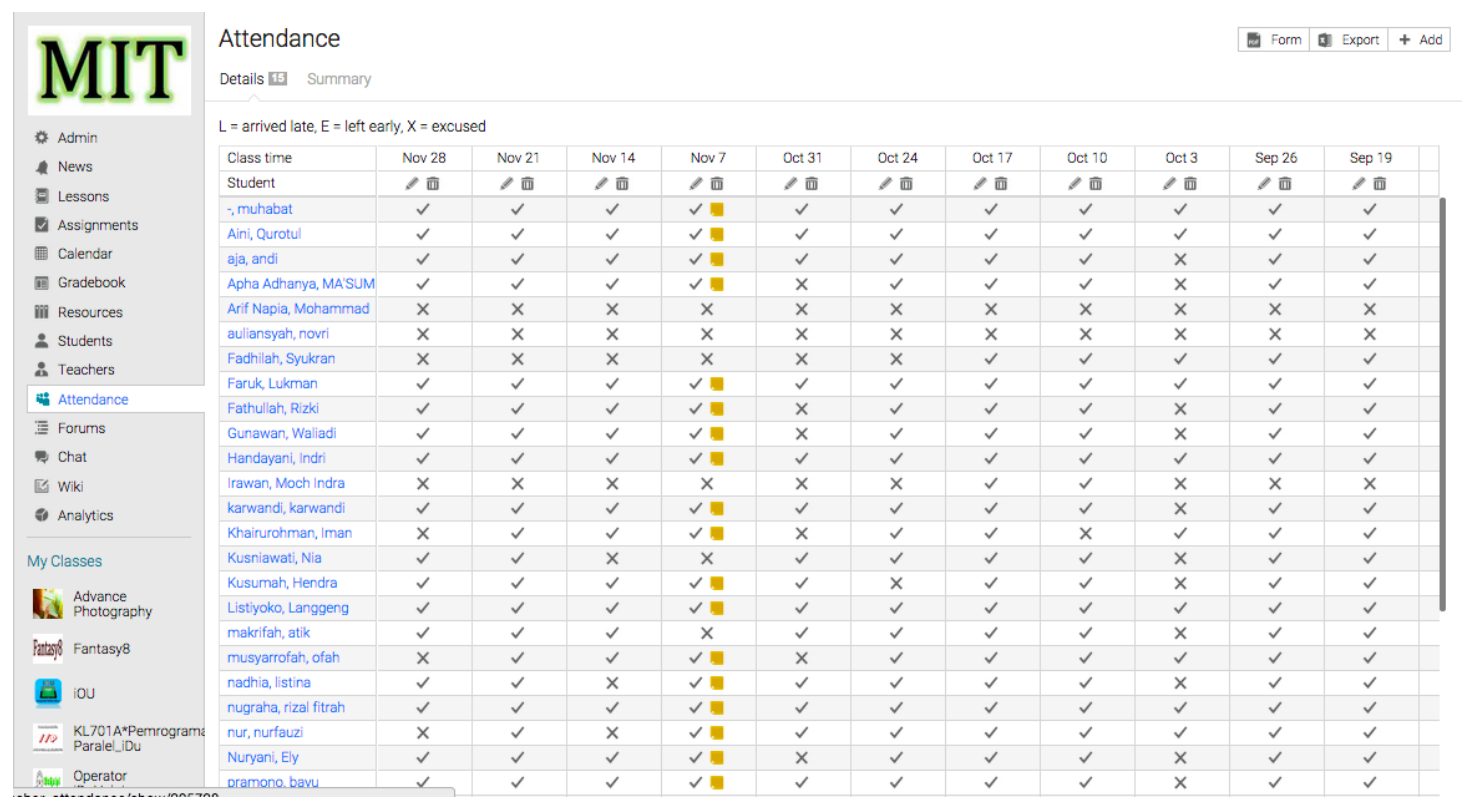

h. Tampilan Analytics pada $i D u$

Dalam analytics berisikan assignment results yang memudahkan untuk mengetahui grade mahasiswa dalam bentuk statistika dan diagram. 


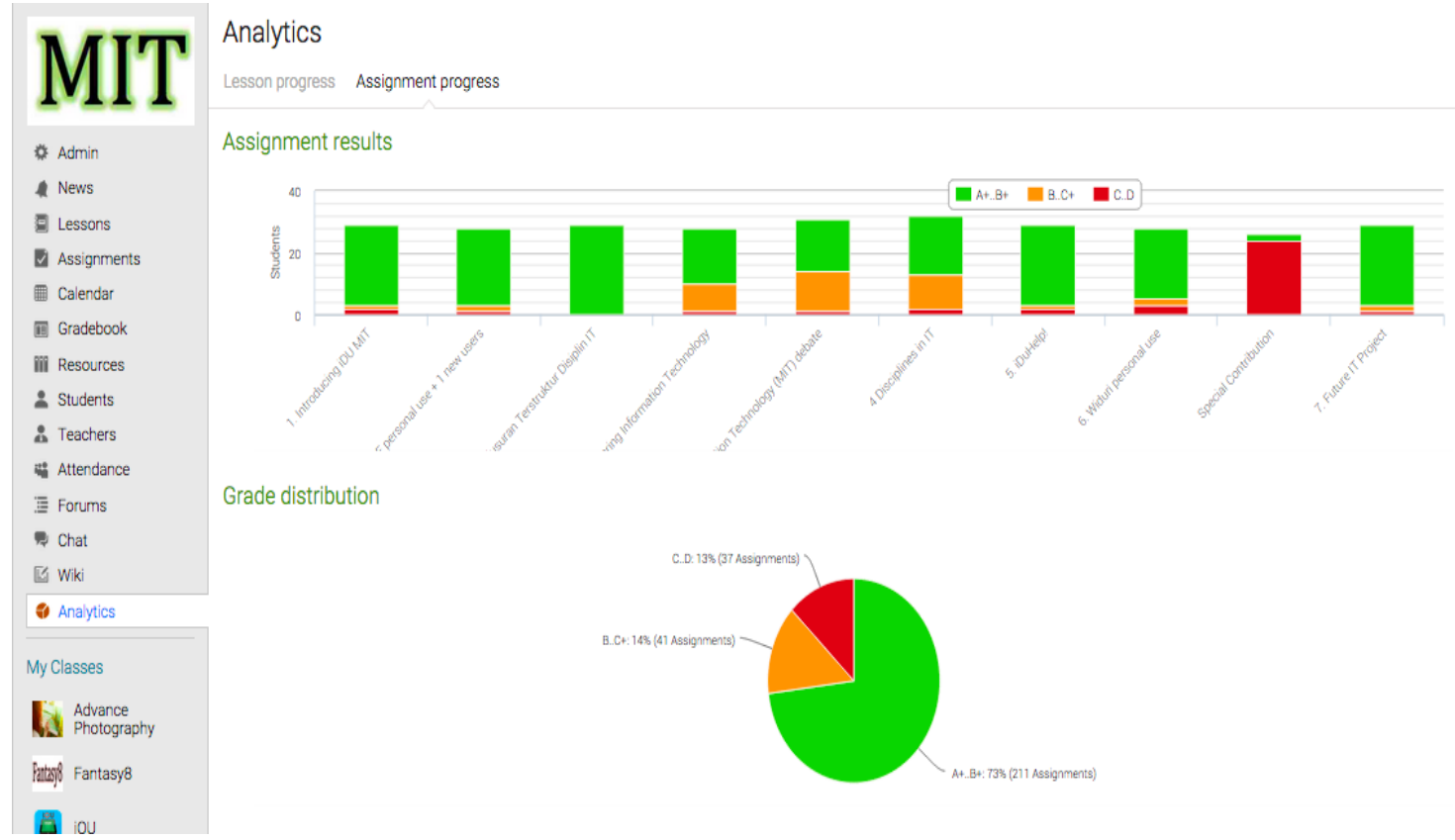

i. Tampilan assignment dari mahasiswa

Dalam assignment ini berisikan seluruh assignment yang diberikan dosen kepada mahasiswa yang lengkap beserta waktu berakhirnya assignment serta grade yang diperoleh.

\begin{tabular}{|c|c|c|c|c|c|c|c|c|}
\hline \multirow{2}{*}{$\sqrt{1} \mathbf{I}^{\top}$} & \multirow{2}{*}{$\begin{array}{l}\text { MIT2 } \\
\text { Assignments } \\
\text { All } \text { 四 Analytics Grademap }\end{array}$} & & & \multicolumn{5}{|c|}{ 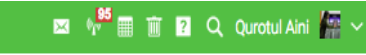 } \\
\hline & & & & & & & & \\
\hline \multirow{2}{*}{$\begin{array}{l}\text { News } \\
\text { Lessons }\end{array}$} & Assignment & Start & Due & $\begin{array}{l}\% \text { of } \\
\text { overall }\end{array}$ & Submitted & Graded & Score & Grade \\
\hline & 7. Future IT Project & $\begin{array}{l}0 \mathrm{ctt} 2 \\
9.00 \mathrm{am}\end{array}$ & $\begin{array}{l}\text { Dec } 6 \\
11: 00 \text { am }\end{array}$ & 30 & $\checkmark$ & $\checkmark$ & $\underset{95 \%}{285 / 300}$ & $\mathrm{At}$ \\
\hline \multirow{2}{*}{$\begin{array}{l}\text { : Calendar } \\
\text { \& Teachers } \\
\text { Students }\end{array}$} & $\begin{array}{l}\text { Special Contribution } \\
\text { (Exra credit) }\end{array}$ & $\begin{array}{l}\text { Sep } 6 \\
9.00 \mathrm{am}\end{array}$ & $\begin{array}{l}\text { Dec } 6 \\
9.00 \mathrm{am}\end{array}$ & 10 & $\checkmark$ & $\checkmark$ & $\begin{array}{c}80 / 100 \\
80 \%\end{array}$ & $A^{*}$ \\
\hline & 6. Widuri personal use & $\begin{array}{l}\text { Oct } 9 \\
10: 00 \mathrm{am}\end{array}$ & $\begin{array}{l}\text { Oct } 16 \\
10: 00 \mathrm{am}\end{array}$ & 7.5 & $\checkmark$ & $\checkmark$ & $\begin{array}{l}75 / 75 \\
100 \%\end{array}$ & At \\
\hline \multirow{2}{*}{$\begin{array}{l}4 \text { Attendance } \\
\text { 『 Wiki } \\
\text { E Portfolio }\end{array}$} & 5. iDuHelp! & $\begin{array}{l}0 \mathrm{ct} 2 \\
200 \mathrm{pm}\end{array}$ & $\begin{array}{l}\text { Oct } 14 \\
1: 00 \mathrm{pm}\end{array}$ & 7.5 & $\checkmark$ & $\checkmark$ & $\begin{array}{l}75 / 75 \\
100 \%\end{array}$ & At \\
\hline & 4 Disciplines in IT & $\begin{array}{l}\text { Sep } 5 \\
4: 00 \mathrm{pm}\end{array}$ & $\begin{array}{l}\text { Oct } 3 \\
3: 00 \mathrm{pm}\end{array}$ & 20 & $\checkmark$ & $\checkmark$ & $200 / 200$ & At \\
\hline My Classes & Whastering Information Technology (MIT) debate & $\begin{array}{l}\operatorname{Sep} 26 \\
6: 30 \mathrm{pm}\end{array}$ & $\begin{array}{l}\mathrm{Sep} 26 \\
8: 00 \mathrm{pm}\end{array}$ & 5 & $\checkmark$ & $\checkmark$ & $\begin{array}{r}50 / 50 \\
100 \%\end{array}$ & At \\
\hline MII' міт2 & Mastering Information Technology & $\begin{array}{l}\text { Sep } 12 \\
7: 00 \mathrm{pm}\end{array}$ & $\begin{array}{l}\text { Sep } 12 \\
8: 00 \mathrm{pm}\end{array}$ & 5 & $\checkmark$ & $\checkmark$ & $\begin{array}{r}50 / 50 \\
100 \%\end{array}$ & At \\
\hline \multirow{2}{*}{ iCP5 } & 3 Penelusuran Terstruktur Disiplin IT & $\begin{array}{l}\text { Aug } 29 \\
4: 00 \mathrm{pm}\end{array}$ & $\begin{array}{l}\text { Sep } 10 \\
4: 00 \mathrm{pm}\end{array}$ & 10 & $\checkmark$ & $\checkmark$ & $\begin{array}{c}100 / 100 \\
100 \%\end{array}$ & At \\
\hline & 2. imE personal use +1 new users & $\begin{array}{l}\text { Aug } 26 \\
10: 00 \mathrm{am}\end{array}$ & $\begin{array}{l}\text { Sep } 2 \\
11: 00 \text { am }\end{array}$ & 10 & $\checkmark$ & $\checkmark$ & $\begin{array}{c}100 / 100 \\
100 \%\end{array}$ & At \\
\hline \multirow{2}{*}{$\begin{array}{l}\text { MIT MIT2 Praktek } \\
\text { PL1028- } \\
\text { Pengantar } \\
\text { Teknologi } \\
\text { Informasi }\end{array}$} & 1. Introducing IDU MIT & $\begin{array}{l}\text { Aug } 22 \\
11: 00 \mathrm{pm}\end{array}$ & $\begin{array}{l}\text { Aug } 26 \\
11: 00 \mathrm{pm}\end{array}$ & 5 & $\checkmark$ & $\checkmark$ & $\begin{array}{c}50 / 50 \\
100 \%\end{array}$ & At \\
\hline & \multicolumn{6}{|c|}{ Overall result } & $107 \%$ & At \\
\hline
\end{tabular}

j. Tampilan Attendance dari mahasiswa

Dalam Attendance ini berisikan summary yaitu waktu kehadiran mahasiswa dalam kelas 


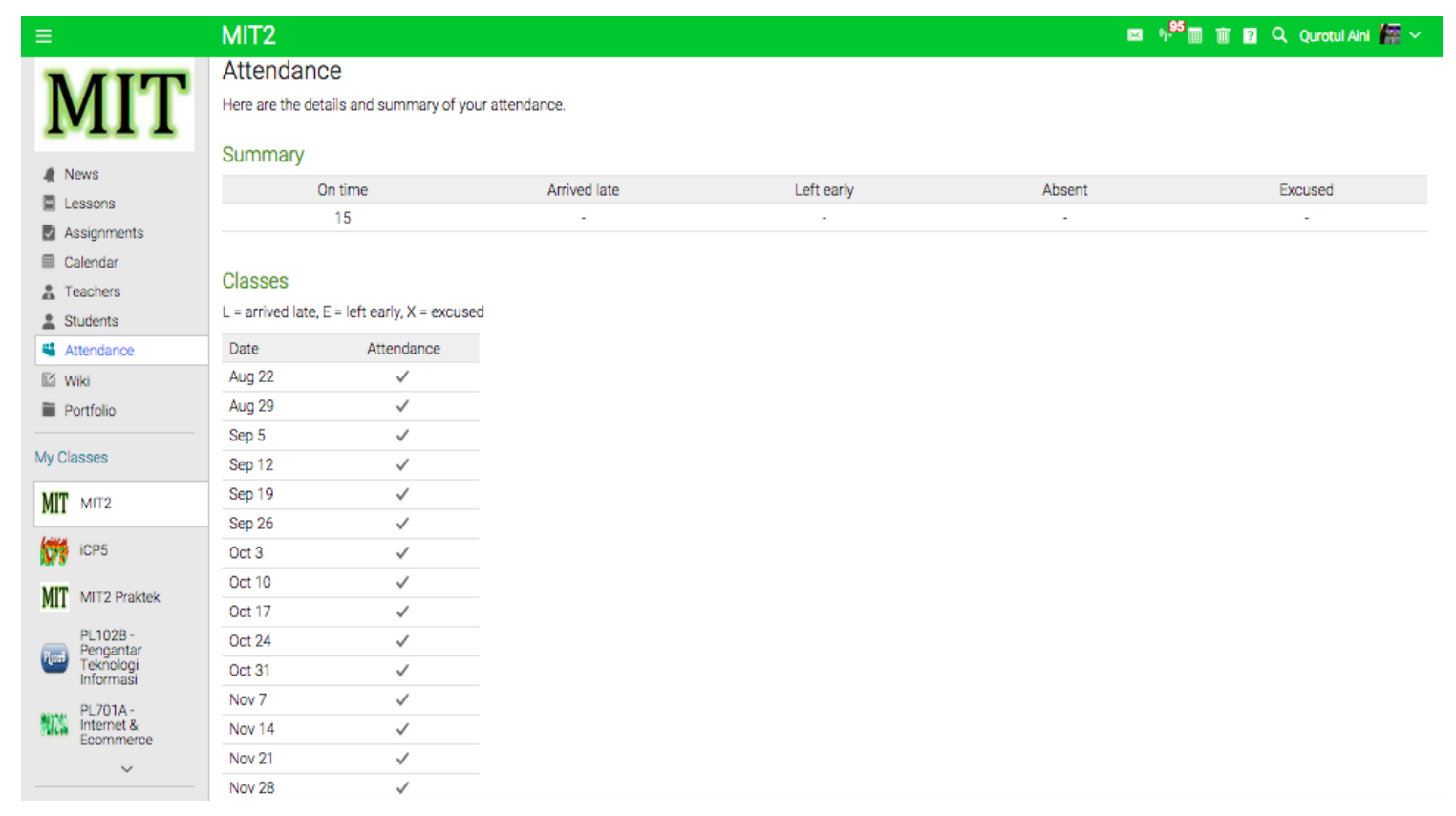

\section{KESIMPULAN}

Demikian dapat disimpulkan bahwa sistem iDu (iLearning Education) yang digunakan oleh Pribadi Raharja. Sistem ini sangat membantu pembelajaran perkuliahan bagi dosen maupun mahasiswa di Perguruan Tinggi Raharja. Dengan sistem ini mahasiswa dapat mengetahui bahan pembelajaran yang dosen berikan sebelum bertatap muka di perkuliahan jadi dapat dipahami terlebih dahulu oleh mahasiswa dirumah, tugas - tugas dan Ujian Online yang tidak takut salah soal ataupun halaman soal yang tidak lengkap, Nilai tugas yang diberikan pun langsung dapat dilihat tanpa harus lama menunggu hasil penilaian terlebih dahulu oleh dosen. iDu (iLearning Education) diharapkan dapat diakses oleh seluruh mahasiswa dimanapun dan kapan pun yang berakses internet. Selain itu juga agar dapat meningkatkan kreativitas serta motivasi mahasiswa dalam belajar. Dan dapat menjadi sarana penunjang yang baik dalam menyampaikan dan memperoleh informasi yang akurat secara online and up to date. Selain itu juga dapat lebih memaksimalkan sistem informasi pembelajaran kampus di Perguruan Tinggi Raharja, adanya sistem pembelajaran kampus online yang dapat dilakukan dimana saja dan kapan saja, meningkatkan kreativitas mahasiswa, meningkatkan motivasi mahasiswa dalam belajar, adanya sistem pembelajaran yang tidak manual, mencerminkan kampus IT dengan memanfaatkan perkembangan teknologi, sehingga dapat memperluas jaringan dan menghasilkan informasi yang akurat. Selain itu, iDu (iLearning Education) juga memiliki tampilan yang user friendly sehingga penggunanya dapat dengan mudah mengenal sistem ini. iDu (iLearning Education) bukan hanya digunakan oleh mahasiswa Perguruan Tinggi Raharja, melainkan juga dosen dan manajemen Perguruan Tinggi Raharja sebagai media informasi bagi seluruh civitas perguruan tinggi dan masyarakat secara umum. iDu (iLearning Education) dapat meningkatkan kreativitas serta motivasi belajar dari mahasiswa, dapat dilakukan dimanapun dan kapanpun, serta dapat dijadikan sebagai media informasi bagi seluruh civitas perguruan tinggi dan masyarakat secara umum. 


\section{DAFTAR PUSTAKA}

[1] Atmoko Nugroho (2012) "Pengembangan Model Pembelajaran Jarak Jauh Berbasis Web (Model Development of Web-Based Distance Learning) Pada Universitas Semarang".Vol. 9 No.2

[2] Dewi Immaniar Desrianti, Untung Rahardja dan Rahma Rinie (2013) “iLearning Metode Belajar Efektif Untuk Sekolah Tinggi”.

[3] Henderi, Muhamad Yusup dan Yulika Ayu Rantama (2013) "Penggunaan Metode iLearning Untuk Meningkatkan Kualitas Pembelajaran di Perguruan Tinggi”. CCIT Journal Vol.6 No.3.

[4] Khanna Tiara, Ray Taufik Wijaya, dan Untung Rahardja (2014) "Penerapan Rinfo Sebagai Media Pendukung Untuk Proses Pembelajaran Pada Perguruan Tinggi Raharja". CCIT Journal Vol.8 No.1.

[5] Maimunah, Kristiana dan Hendra (2010) "Perancangan Aplikasi Forum Diskusi Pada Media E-Learning Berbasis Web Pada Perguruan Tinggi Raharja". CCIT Journal Vol.3 No.2.

[6] Matthew Young Kim, (2011) "Simulation Study of eLearning Classroom using iPads Based on Wireless LAN with IEEE 802.11 b Pada Kennesaw State University Kennesaw, GA, USA."

[7] Meta Amalya Dewi, Dede Cahyadi, Yunita Wulansari (2014) "Sistem Ujian Online Calon Mahasiswa Baru Berbasis iLearning Education Marketing Pada Perguruan Tinggi Raharja". Vol.8 No.1.

[8] Untung Rahardja, Muhamad Yusup dan Eva Rosyifa (2012) "Perancangan Aplikasi iLearning Majalah Online Dengan Menggunakan iOS Programming Pada Perguruan Tinggi”. Vol.6 No.1.

[9] Untung Rahardja, Muhamad Yusup dan Qurotul Aini (2014) "Aplikasi Campus Learning System iOU (integrated Online Ujian) Dalam Mendukung Kegiatan iLearning Education (iDu) Pada Perguruan Tinggi”. Vol.7 No.3. 